\title{
Notes on bat diversity at Berenty Private Reserve and Beza Mahafaly Special Reserve in southern Madagascar
}

\author{
Krista Fish
}

\begin{abstract}
Surveys of bat diversity are rare for the southern domain of Madagascar. Mistnetting for bats took place at Berenty Private Reserve in southeastern Madagascar during a six months study in 2009 and at Beza Mahafaly Special Reserve in southwestern Madagascar for one month in 2011. At Berenty, Hipposideros commersoni, Triaenops rufus, Myotis goudoti, and Miniopterus spp. were captured along trails and clearings inside forests. Two bats, T. rufus and Miniopterus sp., were captured near the Beza Mahafaly Special Reserve. These captures increase the known bat diversity reported for both sites, but more surveys at Berenty and Beza Mahafaly are recommended.
\end{abstract}

\section{RÉSUMÉ}

Dans le Sud de Madagascar, les études sur les chauves-souris sont rares. Des opérations de capture furent conduites dans la réserve privée de Berenty dans le cadre d'une étude de six mois en 2009 puis dans la Réserve Spéciale de Beza Mahafaly pendant un mois en 2011. Avant cette étude à Berenty, la biodiversité microchiroptère de la réserve était méconnue. Hipposideros commersoni, Triaenops rufus, Myotis goudoti et Miniopterus spp. furent capturés le long des sentiers et dans des clairières à Berenty. La capture de $T$. rufus et de Miniopterus sp. près de Beza Mahafaly porta à sept le nombre d'espèces de chauvessouris répertoriées sur le site. Pour les deux réserves, il est souhaitable de mener d'avantage d'études dans des habitats variés et à des saisons différentes. Des spécimens de référence et des échantillons de tissus devraient être collectés afin de faciliter les identifications de certaines espèces de Miniopterus. II est également nécessaire d'estimer la disponibilité en insectes et en dortoirs à Berenty, à Beza Mahafaly et dans d'autres localités malgaches afin de déterminer les facteurs limitants de ces sites.

\section{INTRODUCTION}

Although surveys of bats from the south of Madagascar have been conducted near coastal areas such as Toliara and Taolagnaro (Ranivo and Goodman 2007, Russell et al. 2007, Goodman et al. 2008, Goodman et al. 2009), few assessments exist for southern bat communities further inland. In southeastern Madagascar, bat surveys in humid forests near Taolagnaro revealed three species of megachiropterans and at least nine species of microchiropterans (Goodman et al. 1991, Goodman et al. 1993, Goodman 1999, Goodman et al. 2009). In contrast,

\author{
Colorado College \\ Department of Anthropology \\ Colorado springs, CO, 80903, U.S.A. \\ E-mail: Krista.Fish@coloradocollege.edu
}

the southern domain encompassing the extreme south and southwest is the most arid region of Madagascar. Bat diversity is higher in this region than in the southeast as two species of megachiroptera and at least fourteen microchiropteran species are reported (Goodman et al. 2005, Goodman et al. 2008, Goodman et al. 2009).

As part of a study examining nocturnal mammal ecology, bat activities were investigated at two sites in southern Madagascar: Berenty Private Reserve and Beza Mahafaly Special Reserve. A fruit bat (Pteropus rufus) colony is found at Berenty (Long and Racey 2007, Rahaingodrahety et al. 2008), but to our knowledge this research constitutes the first report on microchiropteran diversity at Berenty. Prior surveys of the bat fauna in and around Beza Mahafaly documented Hipposideros commersoni, Mops midas, Mormopterus jugularis, Taphozous mauritianus, and (rarely) Pteropus rufus (Goodman et al. 1993, Sussman and Ratsirarson 2006, Ratrimomanarivo et al. 2007).

\section{METHODS}

Berenty Private Reserve $\left(\mathrm{E} 46^{\circ} 18, \mathrm{~S} 25^{\circ} 00\right.$ ) is located along the Mandrare River in the southeast of Madagascar, approximately $85 \mathrm{~km}$ west of Taolagnaro (Jolly et al. 2006). The area surrounding Berenty is arid and dominated by spiny forest vegetation characteristic of the southern domain (Jolly et al. 2006). Bats were surveyed in both the Ankoba and Malaza gallery/scrub forests that comprise the main reserve. The two forests (approximately 240 ha) grade into each other in a corridor near several tourist lodges (Jolly et al. 2006) and contain evidence of human disturbances including roads, introduced plants, and water troughs.

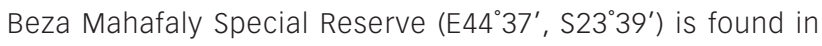
the southwest of Madagascar, approximately $35 \mathrm{~km}$ northeast of Betioky. The research at Beza Mahafaly was conducted in Parcel 1 and an unprotected forest. Parcel 1 is a gallery forest fragment, approximately 80 ha in size and bordered on one side by the Sakamena River. A perimeter fence partially protects this forest from grazing animals (Sussman and Ratsirarson 2006, Youssouf and Rasoazanabary 2008). An intersection of two dirt roads separates Parcel 1 from the neighboring unprotected (approximately. 850 ha) dry, deciduous forest (Axel and Maurer 2010). In the unprotected forest, grazing by goats and cattle has resulted in the loss of groundcover and trees have been cut down so that livestock can feed on their leaves. Zebu cart trails, footpaths, and cattle corrals are found within this forest. 
The bat communities at Berenty and Beza Mahafaly were examined using identical protocols. Bats were captured using 75 denier polyester bat nets (Avinet, Inc). Nets of $2.6 \mathrm{~m} \times 2.6 \mathrm{~m}$ dimensions were placed along trails within forests as nets of this length ensured coverage of trails. Longer $2.6 \mathrm{~m} \times 6 \mathrm{~m}$ nets were used in clearings and unpaved roads. The taxonomy of Malagasy bats was recently revised, but an updated dichotomous key to the bats of Madagascar was unavailable when research was conducted. At both sites, captured bats were identified to species using a key available online (<http://bats. mampam.com/madagascar/Key.htm>) and other reference material (see Taylor 2000, Garbutt 2007). Bats were placed in a soft capture bag and weighed using a $100 \mathrm{~g}$ Pesola scale. Digital calipers (Spi) were used to take metric measurements including body length and forearm length. Hair samples were cut from the bat's dorsum for isotopic analysis. Bats were held in the soft capture bag for up to one hour in order to obtain a fecal sample and then released without additional marking as identification of individual animals was not relevant to our larger study of nocturnal mammal ecology. The removal of dorsal hair prevented recaptured bats from being recounted on the night of capture, but bats may have been recounted on subsequent nights once hair regrew.

Supplementary scans were used to assess bat presence because bats may occur at a site, but avoid capture because they are able to detect nets (Berry et al. 2004). At 10-minutes intervals, a researcher monitoring the mistnet scanned the surrounding area with nightvision binoculars (Night Owl Optics, NOXB5) for one minute. The observation time, height, and activity of any bats detected during the nightvision scan were recorded. During the sampling interval, the researcher also used a bat detector (Stag Electronics, Batbox III) to survey for bat echolocation calls.

Between January and June 2009, 223 hours of netting and supplementary scans were conducted at Berenty during 59 nights. In both the late rainy season (January to March) and early dry season (April to June), nets were set in approximately 4-hours shifts following a sampling schedule that ensured an equal distribution of shifts throughout the night from sunset to sunrise. During 15 nights between June 7 and July 7, 2011, teams of researchers conducted 246 hours of netting along trails and clearings in both Parcel 1 and the unprotected forest at Beza Mahafaly. Ten hours of additional netting occurred along roads outside of Parcel 1. Because of longer austral winter nights and a shorter research schedule, nets at Beza Mahafaly were set in 7-hours shifts with an equal distribution of shifts throughout the night.

\section{RESULTS}

Berenty Private Reserve: The frequency of echolocation calls detected and of bats observed in nightvision scans were higher than the frequency of bat captures (Table 1). Two species of bats from the Family Hipposideridae were captured in the forests of Berenty: Commerson's leaf-nosed bat (Hipposideros commersoni) and the rufus trident bat (Triaenops rufus). At least two different vespertilionid bats were captured at Berenty. The Malagasy mouse-eared bat (Myotis goudoti) was captured once, but bent-wing bats from the genus Miniopterus were the most abundant bat at Berenty. The recent description of several new cryptic species of Miniopterus (Juste et al. 2007, Goodman et al.
TABLE 1. Bats detected and captured from January to June 2009 at Berenty Private Reserve.

\begin{tabular}{|l|c|c|c|c|c|c|}
\hline & January & February & March & April & May & June \\
\hline $\begin{array}{l}\text { Hipposideros } \\
\text { commersoni }\end{array}$ & 1 & 0 & 1 & 0 & 0 & 0 \\
\hline Triaenops rufus & 0 & 0 & 0 & 1 & 0 & 0 \\
\hline Myotis goudoti & 0 & 0 & 1 & 0 & 0 & 0 \\
\hline Miniopterus spp. & 4 & 4 & 8 & 3 & 1 & 0 \\
\hline Total bat captures & 5 & 4 & 10 & 4 & 1 & 0 \\
\hline $\begin{array}{l}\text { Total bats detected } \\
\text { on nightvision }\end{array}$ & 23 & 32 & 28 & 6 & 3 & 0 \\
\hline $\begin{array}{l}\text { Total bat echolo- } \\
\text { cations calls detected }\end{array}$ & 29 & 75 & 57 & 37 & 21 & 6 \\
\hline
\end{tabular}

2008, Goodman et al. 2009) complicated field identification of Miniopterus species. Two variants were identified in the field (Table 2): a small Miniopterus (mass: 3.0 to 7.0 grams; forearm $<40 \mathrm{~mm}$ ) and a large Miniopterus (mass: 7.5 to $10.0 \mathrm{~g}$; forearm $>40 \mathrm{~mm}$ ).

Beza Mahafaly Special Reserve: During the research at Beza Mahafaly, bat echolocation calls were detected 16 times and bats were observed 58 times with nightvision scans. Only two bats were captured at the site. An individual Triaenops rufus, identified as a subadult based on unfused epiphyses in the finger bones, was captured on a zebu cart trail in the unprotected forest habitat. One bent-winged bat was captured on the road adjacent to Parcel 1. Unlike the grayish color of all bent-winged bats captured at Berenty, this individual was reddish in color.

\section{DISCUSSION}

The results of surveys at Berenty and Beza Mahafaly increase our knowledge of bat diversity at both sites. Prior to the research at Berenty, microchiropteran diversity was unknown for the reserve. During this study four species were identified. An additional one to two species of Miniopterus were found in the reserve as well. The capture of Triaenops rufus and Miniopterus $\mathrm{sp}$. at Beza Mahafaly increase the reported bat diversity to seven species. Consistent with the location of mistnets in or near forests, the captured bats are all known clutter-foragers that hunt insects within forested areas (Goodman 1999, Garbutt 2007, Kofoky et al. 2007, Rakotoarivelo et al. 2007, Goodman et al. 2008, Rakotoarivelo et al. 2009). Future research should sample open habitats that may be utilized by aerial-foraging bats. Given that bats may not be equally active in all seasons, surveys should also be undertaken in different seasons to gain a more complete picture of bat diversity and abundance in the two protected areas.

TABLE 2. Body mass and forearm length of bats captured at Berenty Private Reserve and Beza Mahafaly Special Reserve.

\begin{tabular}{|l|c|c|}
\hline Species at Berenty & $\begin{array}{c}\text { Body mass } \\
\text { mean }(\mathrm{g})(\mathrm{n}, \mathrm{SD})\end{array}$ & $\begin{array}{c}\text { Forearm length } \\
\text { mean }(\mathrm{mm})(\mathrm{n}, \mathrm{SD})\end{array}$ \\
\hline Hipposideros commersoni & $60.1(2,19.62)$ & $81.3(2,5.75)$ \\
\hline Triaenops rufus & $10(1,-)$ & $50.6(1,-)$ \\
\hline Myotis goudoti & $6.5(1,-)$ & $35.8(1,-)$ \\
\hline Miniopterus sp. (small) & $5.4(15,1.30)$ & $33.7(15,3.88)$ \\
\hline Miniopterus sp. (large) & $8.6(3,1.5)$ & $41.5(3,1.4)$ \\
\hline Species at Beza Mahafaly & & \\
\hline Triaenops rufus & $6.8(1,-)$ & $47.0(1,-)$ \\
\hline Miniopterus sp. & $6.5(1,-)$ & $38.3(1,-)$ \\
\hline
\end{tabular}


Recent genetic and morphological assessments of Miniopterus (Juste et al. 2007, Goodman et al. 2008, Goodman et al. 2009) revealed that the former $M$. manavi may include several cryptic species with convergent morphology. According to the revised taxonomy, M. manavi and $M$. petersoni are sister taxa (Goodman et al. 2009) with M. manavi found in the central highlands of Madagascar and M. petersoni in the southeast. Given the geographic separation suggested by the newer taxonomy, the 15 captures of small bent-wing bats at Berenty may represent $M$. petersoni. Three bent-wing bats captured at Berenty could not be identified to species in the field as their forearm measurements were larger than those reported for M. petersoni but smaller than those reported for M. majori (Garbutt 2007, Goodman et al. 2009). A fourth unidentified Miniopterus is likely M. petersoni, however it escaped before all measurements could be obtained. A bent-wing bat was also captured at Beza Mahafaly. Based on body mass and forearm measurements this bat likely belonged to $M$. griveaudi or $M$. aelleni which are sympatric in northern and western forests of Madagascar (Goodman et al. 2009). Alternatively, this bat may also represent a color variant of $M$. petersoni, which has been described from the southeast of Madagascar but not the southwest (Goodman et al. 2009). Future researchers at both Berenty and Beza Mahafaly should collect voucher specimens or tissue samples so that genetic information can be utilized to distinguish between the cryptic species of miniopterids (Goodman et al. 2008, Goodman et al. 2009).

Conservation Implications: Given the short duration of the survey at Beza Mahafaly and the time of year in which it was conducted, bat abundances cannot be addressed. However, the results from Berenty raise concerns because of the low number of bat captures relative to an intensive netting effort. For example, during the rainy season, only 19 individual bats of two species were captured in 108 hours of netting at Berenty. In western Madagascar, Rakotoarivelo et al. (2007) captured 162 bats from four species in forest interiors and riparian habitats during 32 hours of rainy season netting. The supplementary bat detection scans and nightvision scans in which researchers documented bats flying over nets suggest that not all bats at the site were captured. However, it is also likely that at least some of these scans resample the same individuals. The evidence suggests that Berenty bat populations are small and possibly at risk of local extinction.

A number of factors may account for the low capture frequencies at Berenty. The isolated forests at Berenty are surrounded by a sisal plantation and other agricultural activities, which may limit migration of bats into Berenty from other locations and prevent repopulation of the reserve. Low insect abundance may also be a factor. The decline in insects at the rainy season-dry season boundary (Fish 2010) may account for the decrease in bat captures during the dry season. Comparative data are needed to determine whether the overall availability of insects at Berenty is lower than at other locations in Madagascar. Another explanation may be a lack of roost sites. No rock overhangs or caves were discovered during surveys for roost sites at Berenty. Restaurants, bungalows, and outbuildings in the reserve were examined and neither roosting bats nor evidence of previous roosts were discovered. Future investigations should survey neighboring villages, which contain buildings that may support bat roosts. Finally, bats are prey items in parts of Madagascar (Goodman 2006, Jenkins and Racey 2008) and hunting pressure may be particularly high in the south which experiences frequent droughts and famines (Nussbaum and Raxworthy 2000, Jolly et al. 2006).

\section{CONCLUSIONS}

This research expands the known diversity of bats at Berenty Private Reserve to include the microchiropterans Hipposideros commersoni, Triaenops rufus, Myotis goudoti, and Miniopterus spp. At Beza Mahafaly Special Reserve, the captures of T. rufus and Miniopterus sp. increase the reported bat diversity to seven species. Future studies at both sites should include the collection of tissue samples or voucher specimens, surveys in different habitat types, and surveys during different seasons. Additional information on roost availability, insect prey, and potential predators including humans should be collected in investigate potential limiting factors at different localities throughout southern Madagascar.

\section{ACKNOWLEDGMENTS}

I would like to thank the individuals and organizations that contributed to the completion of both the Berenty and Beza Mahafaly portions of this research project. The staff of MICET (Madagascar Institut pour la Conservation des Ecosystèmes Tropicaux) assisted in the acquisition of research visas and permits. The de Heaulme family graciously granted permission for the research at Berenty Private Reserve and provided accommodations during our stay at the reserve. Dr. Alison Jolly facilitated our work at Berenty while Radoniaina (Rado) Nasolo Rabemaharavonirina assisted the research. The project at Berenty was funded by Sigma Xi, The University of Colorado Museum, the American Society of Primatologists, and the University of Colorado Beverly Sears Graduate Student Grant program. The research at Beza Mahafaly was made possible by a Colorado College Social Sciences Executive Committee Grant and Colorado College Venture Funds. I am indebted to the entire staff at the Beza Mahafaly Special Reserve. Research assistants at Beza Mahafaly who made the research possible include Ramboazafy (Vola) Anjarasoaniana, Kyleen Breslin, Laura Broudy, Joshua Sodowsky, and Sarah Soffer. Dr. Jacky Youssouf facilitated the research at Beza Mahafaly and provided important information about the site, surrounding villages, and the nocturnal mammal community. Drs. Michelle Sauther and Frank Cuozzo provided guidance and logistical support on both the Berenty and Beza Mahafaly projects. Dr. Dave Armstrong, Dr. Frank Cuozzo, and three anonymous reviewers provided many helpful comments that greatly improved this manuscript.

\section{REFERENCES}

Axel, A. C. and Maurer, B. A. 2010. Lemurs in a complex landscape: Mapping species density in subtropical dry forests of southwestern Madagascar using data at multiple levels. American Journal of Primatology 73,1: 38-52. (doi:10.1002/ajp.20872)

Berry, N., O'Connor, W., Holderied, M. W. and Jones, G. 2004. Detection and avoidance of harp traps by echolocating bats. Acta Chiropterologica 6, 2: 335-346.

Fish, K. D. 2010. Niche Separation Between Mouse Lemurs (Microcebus murinus) and Clutter-foraging Bats at Berenty Private Reserve, Madagascar. Unpubl. Ph.D. thesis, University of Colorado, Boulder.

Garbutt, N. 2007. Mammals of Madagascar: A Complete Guide. Yale University Press, New Haven. 
Goodman, S. M. 1999. Notes on the bats of the Réserve Naturelle Intégrale d'Andohahela and surrounding areas of southeastern Madagascar. Fieldiana: Zoology 94: 251-257.

Goodman, S. M. 2006. Hunting of microchiroptera in south-western Madagascar. Oryx 40, 2: 225-228. (doi:10.1017/s0030605306000354)

Goodman, S. M., Creighton, G. K., Raxworthy, C. 1991. The food habits of the Madagascar long-eared owl Asio madagascariensis in southeastern Madagascar. Bonner Zoologische Beiträge 42, 1: 21-26.

Goodman, S. M., Langrand, O. and Raxworthy, C. J. 1993. Food habits of the Madagascar long-eared owl Asio madagascariensis in two habitats in southern Madagascar. Ostrich 64, 2: 79-85. (doi:10.1080/00306525.19 93.9634209)

Goodman, S. M., Andriafidison, D., Andrianaivoarivelo, R., Cardiff, S. G., Ifticene, E., Jenkins, R. K. B., Kofoky, A., Mbohoahy, T., Rakotondravony, D., Ranivo, J., Ratrimomanarivo, F., Razafimanahaka, J. and Racey, P. A. 2005. The distribution and conservation of bats in the dry regions of Madagascar. Animal Conservation 8, 2: 153-165. (doi:10.1017/ S136794300500199X)

Goodman, S. M., Bradman, H. M., Maminirina, C. P., Ryan, K. E., Christidis, L. L. and Appleton, B. 2008. A new species of Miniopterus (Chiroptera: Miniopteridae) from lowland southeastern Madagascar. Mammalian Biology 73, 3: 199-213. (doi:10.1016/j.mambio.2007.12.003)

Goodman, S. M., Maminirina, C. P., Weyeneth, N., Bradman, H. M., Christidis, L., Ruedi, M. and Appleton, B. 2009. The use of molecular and morphological characters to resolve the taxonomic identity of cryptic species: The case of Miniopterus manavi (Chiroptera, Miniopteridae). Zoologica Scripta 38, 4:339-363. (doi:10.1111/j.1463-6409.2008.00377.x)

Jenkins, R. K. B and Racey, P. A. 2008. Bats as bushmeat in Madagascar. Madagascar Conservation \& Development 3,1: 22-29.

Jolly, A., Koyama, N., Rasamimanana, H., Crowley, H. and Williams, G. 2006. Berenty Reserve: A research site in southern Madagascar. In: Ringtailed Lemur Biology: Lemur catta in Madagascar. A. Jolly, R.W. Sussman, N. Koyama, and H. Rasamimanana (eds.), pp. 32-42. Springer, New York. (doi:10.1007/978-0-387-34126-2_3)

Juste, J., Ferrandez, A., Fa, J. E., Masefield, W. and Ibanez, C. 2007. Taxonomy of little bent-winged bats (Miniopterus, Miniopteridae) from the African islands of Sao Tomé, Grand Comoro and Madagascar, based on mtDNA. Acta Chiropterologica, 9, 1: 27-37. (doi:10.3161/17335329(2007)9[27:TOLBBM]2.0.CO;2)

Kofoky, A. F., Andriafidison, D., Ratrimomanarivo, F., Razafimanahaka, H. J., Rakotondravony, D., Racey, P. A. and Jenkins, R. K. B. 2007. Habitat use, roost selection and conservation of bats in Tsingy de Bemaraha National Park, Madagascar. Biodiversity Conservation 16, 4: 1039-1053. (doi:10.1007/s10531-006-9059-0)
Long, E. and Racey, P. A. 2007. An exotic plantation crop as a keystone resource for an endemic megachiropteran, Pteropus rufus, in Madagascar. Journal of Tropical Ecology 23:397-407. (doi:10.1017/ S0266467407004178)

Nussbaum, R. A. and Raxworthy, C. J. 2000. Commentary on conservation of "Sokatra," the radiated tortoise (Geochelone radiata) of Madagascar. Amphibian and Reptile Conservation 2,1: 6-14.

Rahaingodrahety, V. N., Andriafidison, D., Ratsimbazafy, J. H., Racey, P. A. and Jenkins, R. K. B. 2008. Three flying fox (Pteropodidae: Pteropus rufus) roosts, three conservation challenges in southeastern Madagascar. Madagascar Conservation \& Development 3, 1: 17-21.

Rakotoarivelo, A. A., Ranaivoson, N., Ramilijaona, O. R., Kofoky, A. F., Racey, P. A. and Jenkins, R. K. B. 2007. Seasonal food habits of five sympatric forest microchiropterans in western Madagascar. Journal of Mammalogy 88, 4: 959-966. (doi:10.1644/06-MAMM-A-112R1.1)

Rakotoarivelo, A. A., Ralisata, M., Ramilijaona, O. R., Rakotomalala, M. R., Racey, P. A, and Jenkins, R. K. B. 2009. The food habits of a Malagasy giant: Hipposideros commersoni (E. Geoffroy, 1813). African Journal of Ecology 47, 3: 283-288. (doi:10.1111/j.1365-2028.2008.00947.x)

Ranivo, J. and Goodman, S. M. 2007. Patterns of ecomorphological variation in the bats of western Madagascar: Comparisons among and between communities along a latitudinal gradient. Mammalian Biology. 72, 1 : 1-13. (doi:10.1016/j.mambio.2006.08.004)

Ratrimomanarivo, F.H., Vivian, J., Goodman, S.M. and Lamb, J. 2007. Morphological and molecular assessment of the specific status of Mops midas (Chiroptera: Molossidae) from Madagascar and Africa. African Zoology 42, 2: 237-253. (doi:10.3377/15627020(2007)42[237:MAMAOT]2.0.CO;2)

Russell, A. L., Ranivo, J., Palkovacs, E. P., Goodman, S. M. and Yoder, A. D. 2007. Working at the interface of phylogenetics and population genetics: A biogeographical analysis of Triaenops spp. (Chiroptera: Hipposideridae). Molecular Ecology. 16, 4: 839-851. (doi:10.1111/ j.1365-294X.2007.03192.X)

Sussman, R. W. and Ratsirarson, J. 2006. Beza Mahafaly Special Reserve: A Research Site in Southwestern Madagascar. In: Ringtailed Lemur Biology: Lemur catta in Madagascar. A. Jolly, R.W. Sussman, N. Koyama, and H. Rasamimanana (eds.), pp. 43-51. Springer,. New York. (doi:10.1007/978-0-387-34126-2_4)

Taylor, P. J. 2000. Bats of Southern Africa. University of Natal Press, Pietermaritzburg.

Youssouf Jacky, I. A. and Rasoazanabary, E. 2008. Discovery of Macrotarsomys bastardi at Beza Mahafaly Special Reserve, southwest Madagascar, with observations on the dynamics of small mammal interactions. Madagascar Conservation \& Development 3, 1: 31-37. 